\title{
EPA and the Perrin Technique: a combined approach to treating myalgic encephalomyelitis
}

\author{
Raymond Perrin \\ From $1^{\text {st }}$ International Congress on Neurobiology and Clinical Psychopharmacology and European \\ Psychiatric Association Conference on Treatment Guidance \\ Thessaloniki, Greece. 19-22 November 2009
}

Research over the past twenty years by the author into the bio-mechanical aspects of Chronic Fatigue Syndrome/Myalgic Encephalomyelitis has led to a hypothesis that a common aetiological pathway involves an insult to the lymphatic drainage of toxins from the central nervous system. Hypothalamic involvement in the pathogenesis of CFS/ME is discussed.

The ensuing neurotoxicity due to infection, pollution and emotional or physical trauma may lead to excess of neurotransmitters such as acetylcholine due to autonomic over-activity.

Indeed an increase of choline has been found in the occipital cortex of CFS/ME sufferers. (Excess breakdown in acetylcholine could lead to high levels of choline in the brain). Damage to the phospholipid bonds from neurotoxins is shown to be repaired by the additional supplementation of EPA. By combining the EPA with The Perrin Technique (a manual treatment combining lymphatic drainage, spinal and cranial osteopathy) it is argued that the neurotoxins are drained away from the central nervous system thus leading to a lasting improvement in the health of CFS/ME patients.

Published: 22 April 2010

doi:10.1186/1744-859X-9-S1-S25

Cite this article as: Perrin: EPA and the Perrin Technique: a combined approach to treating myalgic encephalomyelitis. Annals of General Psychiatry 2010 9(Suppl 1):S25.

School of Public Health and Clinical Sciences, UCLAN, UK
Submit your next manuscript to BioMed Central and take full advantage of:

- Convenient online submission

- Thorough peer review

- No space constraints or color figure charges

- Immediate publication on acceptance

- Inclusion in PubMed, CAS, Scopus and Google Scholar

- Research which is freely available for redistribution 